\title{
7.6 Million Fewer Births and Still Counting
}

\author{
Kenneth M. Johnson
}

$\mathrm{N}$ ational Center for Health Statistics data for 2020 show just 3,605,000 births, 3.8 percent fewer than in 2019 and the fewest since 1979. There were 711,0000 fewer births in 2020 than in 2007, just before the Great Recession began to influence births: a 16.5 percent decrease. This birth decline occurred even though there were 8.5 percent more women aged 15-44 in 2020 than in 2007. Births diminished because of significantly lower fertility rates among women 15-34 in 2020. Had 2007 fertility patterns been sustained through 2020, there would have been 7.6 million more births and 3 million more firsttime mothers in the last 13 years. This trend is unlikely to change in the shortterm because of the pandemic's adverse impact on fertility. Nine months after the pandemic began, its first effects on births are illustrated in December 2020 births, which declined 7.7 percent from a year earlier. A critical long-term question is: how many births are being delayed, and how many will be foregone? Women who delayed fertility because of the Great Recession and its aftermath are now further challenged by COVID-19. This has implications for health care, schools, childrelated businesses, and eventually for the labor force.

\section{ACTUAL BIRTHS COMPARED TO BIRTHS USING 2007 BIRTH RATES, 2007 T0 2020}

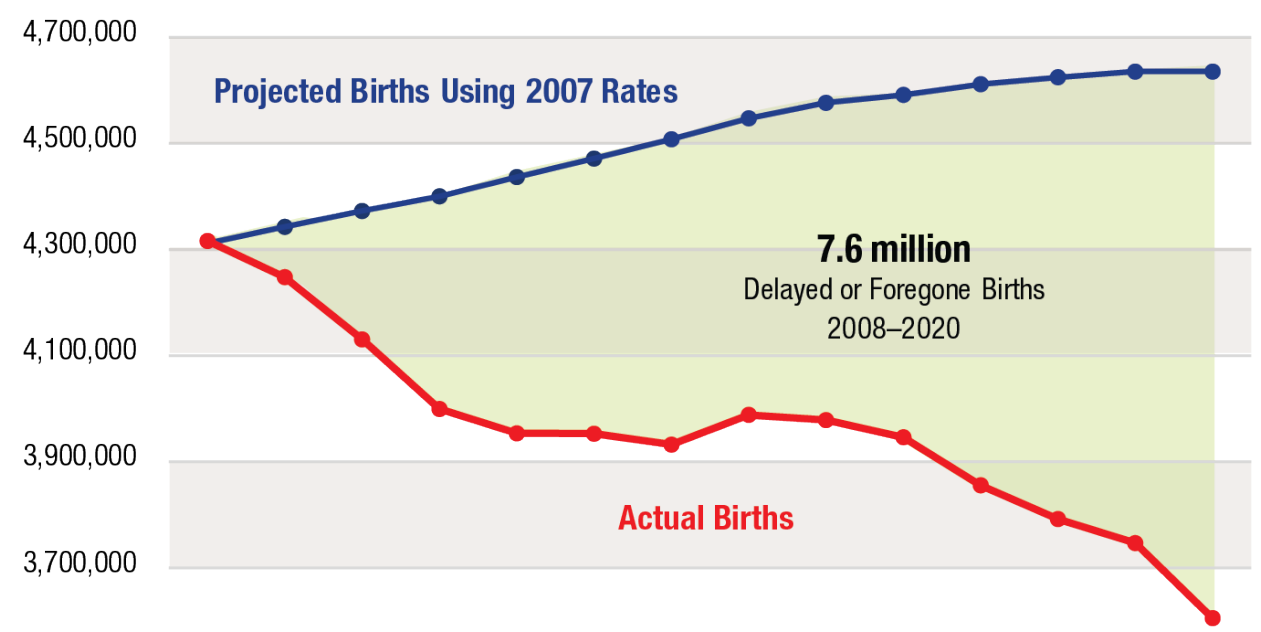

$3,500,000$

20072008200920102011201220132014201520162017201820192020

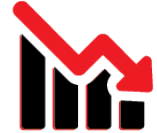

In 2020, the U.S. had the fewest births in $\mathbf{4 0}$ years. Over the past 13 years, there have been 7.6 million fewer births than would have been expected given pre-Great Recession fertility rates.

\section{See Related Publications at carsey.unh.edu}

- Deaths Exceeded Births in a Record Number of States in 2020 (May 2021)

- 2020 Census Reflects Lagging U.S. Population Growth (April 2021)

About the Author

Kenneth M. Johnson is senior demographer at the Carsey School of Public Policy, professor of sociology at the University of New Hampshire, and an Andrew Carnegie Fellow. His research was supported by the Carnegie Corporation. The opinions are his and not those of the sponsoring organization. 